九州大学学術情報リポジトリ

Kyushu University Institutional Repository

\title{
Activated Carbon from Bagasse and its Application for Water Vapor Adsorption
}

\section{Arikasuci Fitonna Ridassepri}

Research Group of Solid State Chemistry and Catalysis, Chemistry Department, Sebelas Maret University

\section{Rahmawati, Fitria}

Research Group of Solid State Chemistry and Catalysis, Chemistry Department, Sebelas Maret University

\section{Kinkind Raras Heliani}

Research Group of Solid State Chemistry and Catalysis, Chemistry Department, Sebelas Maret University

\section{Chairunnisa}

Department of Advanced Device Materials, Institute for Materials Chemistry and Engineering, Kyushu University

他

https://doi.org/10.5109/4068621

出版情報 : Evergreen. 7 (3)，pp.409-416，2020-09. 九州大学グリーンテクノロジー研究教育センター バージョン：

権利関係 : 


\title{
Activated Carbon from Bagasse and its Application for Water Vapor Adsorption
}

\author{
Arikasuci Fitonna Ridassepri ${ }^{1,2}$, Fitria Rahmawati ${ }^{1, *}$, Kinkind Raras Heliani ${ }^{1}$, \\ Chairunnisa $^{3}$, Jin Miyawaki ${ }^{3}$, Agung Tri Wijayanta ${ }^{4}$ \\ ${ }^{1}$ Research Group of Solid State Chemistry and Catalysis, Chemistry Department, Sebelas Maret University, \\ Indonesia \\ ${ }^{2}$ Chemistry Department, Faculty of Mathematics and Natural Sciences, Sebelas Maret University, Indonesia \\ ${ }^{3}$ Department of Advanced Device Materials, Institute for Materials Chemistry and Engineering, Kyushu \\ University, Japan
}

${ }^{4}$ Research Group of Sustainable Thermofluids, Mechanical Engineering, Sebelas Maret University, Indonesia

*Author to whom correspondence should be addressed:

E-mail: fitria@mipa.uns.ac.id

(Received December 2, 2019; Revised May 21, 2020; accepted September 3, 2020).

\begin{abstract}
This research study carbon activation prepared from Bagasse, a waste of sugar factory. The activation was conducted in water vapor at $600^{\circ} \mathrm{C}(\mathrm{C} 600)$ and $700{ }^{\circ} \mathrm{C}(\mathrm{C} 700)$. The activated carbon was then tested for water vapor adsorption. The produced-carbon has diffraction peak at $2 \theta$ of $25^{\circ}$, with surface area are $584.940 \mathrm{~m}^{2} / \mathrm{g}$ and $533.301 \mathrm{~m}^{2} / \mathrm{g}$ for C600 and C700, respectively. C600 also shows higher water vapor adsorption than C700, the value is $0.223 \mathrm{~g} / \mathrm{g}$. It shows a potency of Bagasse waste as raw material for adsorbent powder.
\end{abstract}

Keywords: Bagasse, Activated Carbon, Water Vapor Adsorption.

\section{Introduction}

Indonesia is the top 10 sugar cane producer in the world Sugarcane Biofuel Production ${ }^{1)}$ with sugar cane plantation area spread over at around 420,146 hectares (Ha) in 20172). The production of sugar cane can reach $2,465,450$ tons annually ${ }^{3}$. Bagasse is the remaining sugar cane after being crushed to extract sugar juice for sugar production. Bagasse contains short fiber, water, and a small amount of soluble solid ${ }^{4}$. In every 10 tons of sugarcane process will produce around 3 tons of bagasse ${ }^{5)}$, such a high amount that causes harm environment for long period. Therefore, some efforts to change bagasse for a useful material is expected to solve the problem. It is supported by the high cellulose content within the bagasse. The detail composition are 50\% cellulose, $25 \%$ lignin and $25 \%$ hemicellulose ${ }^{4,6,7)}$. The high cellulose content is an important point to choose the bagasse for raw material carbon production ${ }^{8-10}$ ). Carbon-based materials are functional for many purposes such as for gas adsorption ${ }^{11,12)}$, wastewater treatment ${ }^{13)}$, electrodes in media storage ${ }^{14,15)}$, antibacterial agent ${ }^{16)}$, gas storage ${ }^{17}$, and for photocatalytic uses ${ }^{18)}$. The effort to change bagasse as a sugarcane factory waste into activated carbon is important to increase the economic value of bagasse along with its solution to waste management regarding environmental issues.

As a porous-high surface area material, activated carbon is commonly used as an adsorbent in separation system, and also in purification of liquid and gasses. The activated carbon has its adsorption capacity related to its porosity, surface area, pore volume, and also pore size distribution ${ }^{19,20)}$. It also has ability to adsorb humidity or water vapor. Some countries, especially tropical countries are known to have mean temperature of day and night at around $30{ }^{\circ} \mathrm{C}$ and $20{ }^{\circ} \mathrm{C}$ respectively, with high relative humidity in the range $80 \%-90 \%{ }^{21)}$. High humidity leads to the growth of bacterias, ticks, and fungi that makes human health problems, such as the allergic reaction of bacterias, ticks, and fungi that ignites asthma and atopic diseases. Moreover, humidity also can cause structural damage to the wall and some equipments ${ }^{22,23)}$.

The adsorption capacity of activated carbon is expected to become a problem solution to control humidity ${ }^{12,24-26)}$. Adsorption of water vapor occurs at polar sites, and then subsequently adsorbed onto those previous-adsorbed-water molecules. The adsorption occurs through the hydrogen bonding ${ }^{25)}$.

Carbon activation can be conducted through physical or chemical method. Physical method uses high temperature and gas flow such as water vapor, $\mathrm{CO}_{2}$, and 
$\mathrm{N}_{2}{ }^{27-30)}$, meanwhile, chemical activation uses chemical additives to the carbon, followed by heating treatment under inert gas atmosphere ${ }^{27,28)}$. Physical activation is more environmental friendly, more simple and inexpensive. Among of the gas for physical activation, water vapor or steam activation might be the cheapest one, despite of its ability to increase the oxygen content that plays an important role in the humidity adsorption ${ }^{31)}$.

The activation temperature played an important role in porosity and surface area ${ }^{32,33)}$ which influenced the adsorption capacity of activated carbon. The activation required a high activation temperature (600$\left.1000{ }^{\circ} \mathrm{C}\right)^{25,33,34)}$. Sun et al., (2019) synthesized activated carbon from coffee-shell using activation temperature at $600-900^{\circ} \mathrm{C}$. The result showed that the surface area increase as the activation temperature increase ${ }^{28)}$. Meanwhile, a study on activated carbon that synthesized from barley straw found that steam activation at $600{ }^{\circ} \mathrm{C}$ was not sufficient to produce appropriate porosity and surface area. Steam activation at $700{ }^{\circ} \mathrm{C}$ produced high surface area of $552 \mathrm{~m}^{2} / \mathrm{g}$ within micro-porous pore category. Further increasing to $800{ }^{\circ} \mathrm{C}$ even lower the surface area and pore volume ${ }^{34)}$. Another study also conducted activation at $\quad 600{ }^{\circ} \mathrm{C}$ and $700{ }^{\circ} \mathrm{C}$ and produce mesopore type carbon at $700{ }^{\circ} \mathrm{C}^{32}$. Therefore, in this research the carbonation result of bagasse was steam activated at $600{ }^{\circ} \mathrm{C}$ and $700{ }^{\circ} \mathrm{C}$. The activated-powder was then characterized to understand its specific diffraction pattern, the functional group vibration at before and after activation, the elemental analysis, and $\mathrm{N}_{2}$ isotherm adsorption. Further investigation was subjected to check the capability of water vapor adsorption of activated carbon at $20^{\circ} \mathrm{C}$ and $30{ }^{\circ} \mathrm{C}$ as the room temperature of tropical countries lies between both temperatures.

\section{Experimental}

\subsection{Pretreatment of bagasse}

The bagasse was collected from sugar cane factory in Kudus, Central Java, Indonesia. Bagasse was washed and soaked in distilled water for 24 hours. Wet bagasse was dried in oven at $120{ }^{\circ} \mathrm{C}$ for 24 hours to eliminate any remaining moisture and avoid condensation during experiment ${ }^{34)}$.

\subsection{Synthesis of Activated Carbon}

Amount of bagasse was carbonized in a furnace under $\mathrm{N}_{2}$ flow within $200 \mathrm{~cm}^{3} / \mathrm{min}$ rate flow, at $600{ }^{\circ} \mathrm{C}$ for 30 min with heating rate of $18{ }^{\circ} \mathrm{C} / \mathrm{min}$. The carbonizedproduct was then cooled to room temperature in $\mathrm{N}_{2}$ atmosphere. After weighing to know carbonization yield with equation (1), the next step was activation process under $600{ }^{\circ} \mathrm{C}$ and $700{ }^{\circ} \mathrm{C}$ for $1 \mathrm{~h}$ with heating rate of $18{ }^{\circ} \mathrm{C} / \mathrm{min}$ under steam flow. The activation was conducted within an installed-tube furnace as described in Fig. 1. Steam was produced by boiled water at $120^{\circ} \mathrm{C}$ and flow the steam into the furnace with $\mathrm{N}_{2}$ carrier flow. The activation results were weighted to calculate mass degradation and \% yield with equation (2) and (3). Carbon that were activated at $600{ }^{\circ} \mathrm{C}$ and $700{ }^{\circ} \mathrm{C}$ denoted as C600 and C700, respectively.

$$
\begin{aligned}
& \mathrm{y}_{1}=\frac{\mathrm{m}_{2}}{\mathrm{~m}_{1}} \times 100 \% \\
& y_{2}=\frac{m_{4}}{m_{3}} \times 100 \% \\
& y_{3}=\frac{m_{4}}{m_{1}} \times 100 \%
\end{aligned}
$$

\subsection{Materials characterization}

The prepared-material was analyzed by X-Ray Diffraction (Rigaku Miniflex600) with $\mathrm{Cu} / \mathrm{K} \alpha$ radiation ranging from $0^{\circ}$ to $80^{\circ}$ to understand its specific diffraction pattern. Fourier Transform Infrared, FTIR (Shimadzu IR Prestige-2) analysis was conducted within 4000-400 $\mathrm{cm}^{-1}$ wavenumber to analyze its functional groups vibration at before and after activation. Elemental analysis was carried out by Yanaco CHN Corder MT-5. The isotherms of $\mathrm{N}_{2}$ were measured at $77 \mathrm{~K}$ at a relative pressure.

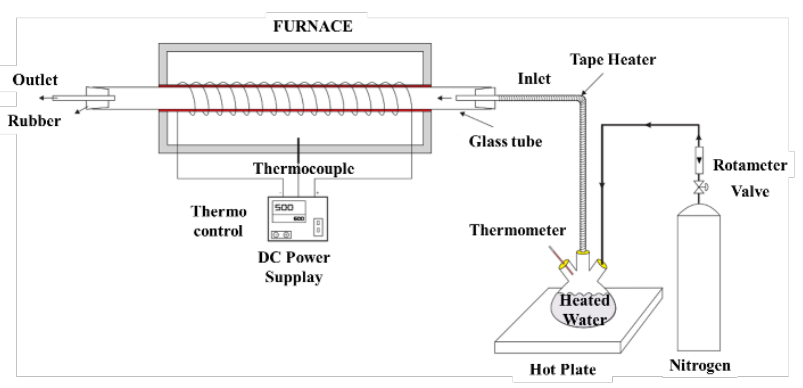

Fig. 1: Scheme of installed-tube furnace for the activation stage

\subsection{Water vapor adsorption}

The water vapor adsorption capacity and isotherm of adsorption-desorption of activated carbon were carried out at $20{ }^{\circ} \mathrm{C}$ and $30{ }^{\circ} \mathrm{C}$ at a relative pressure using a magnetic suspension adsorption measurement unit (MSBVG-S2) provided by Bel Japan. The weight of adsorbed water vapor was measured up to a corresponding saturation pressure. Adsorption isotherm was obtained by plotting the amount of adsorbed water vapor to the increasing of the relative pressure. Meanwhile, desorption isotherm was determined from the amount of water vapor released by the activated-carbon when the pressure decreased.

\section{Result and discussion}

The carbonization stage produced a black powder at $26.43 \%$ yield, $\mathrm{y}_{1}$. The weight loss after carbonization was originated from the degradation of cellulose, unstable components, and lignin in bagasse ${ }^{28)}$. The activated 
carbon yields are shown in Table 1 . Table 1 shows that activation temperature at $600{ }^{\circ} \mathrm{C}$ (C600) produced activation yield $\left(\mathrm{y}_{2}\right)$ and total yield $\left(\mathrm{y}_{3}\right) 76.72 \%$ and $18.12 \%$ respectively, while activation temperature at $700{ }^{\circ} \mathrm{C}$ (C700) has activation yield ( $\left.\mathrm{y}_{2}\right)$ and total yield $\left(\mathrm{y}_{3}\right)$ $68.64 \%$ and $17.85 \%$ respectively. The result shows that the percentage of yield decrease as the temperature increase. The result is in line with a previous research in an adsorbent which was physically activated ${ }^{27)}$. Lower yield found at a high activation temperature might be caused by the fast activation rates allowed more carbon to be burned and more unstable compounds to be released 27,28).

Table 1. The yield of activation (\%) and the total yield (\%) at $600{ }^{\circ} \mathrm{C}$ and $700{ }^{\circ} \mathrm{C}$

\begin{tabular}{|l|l|l|l|}
\hline Sample & Temperature $\left.\mathbf{(}^{\circ} \mathrm{C}\right)$ & $\begin{array}{l}\text { Activation } \\
\text { Yield (\%) }\end{array}$ & $\begin{array}{l}\text { Total } \\
\text { Yield (\%) }\end{array}$ \\
\hline C600 & 600 & 76.72 & 18.12 \\
\hline C700 & 700 & 68.64 & 17.85 \\
\hline
\end{tabular}

The XRD patterns of char, C600, and C700 are displayed in Fig. 2. The XRD patterns show a broad peak centered at $2 \theta=25^{\circ}$ corresponds to the (002) lattice plane of carbon (JCPDS no 41-1487). The broad peak confirms the amorphous phase of chars. This is in agreement with some researches on carbonization and activated carbon preparation $^{15,35,36)}$. The XRD patterns of C600 and C700 are similar. It confirms that the activation proceeds in a similar way whether at $600{ }^{\circ} \mathrm{C}$ or $700{ }^{\circ} \mathrm{C}$.

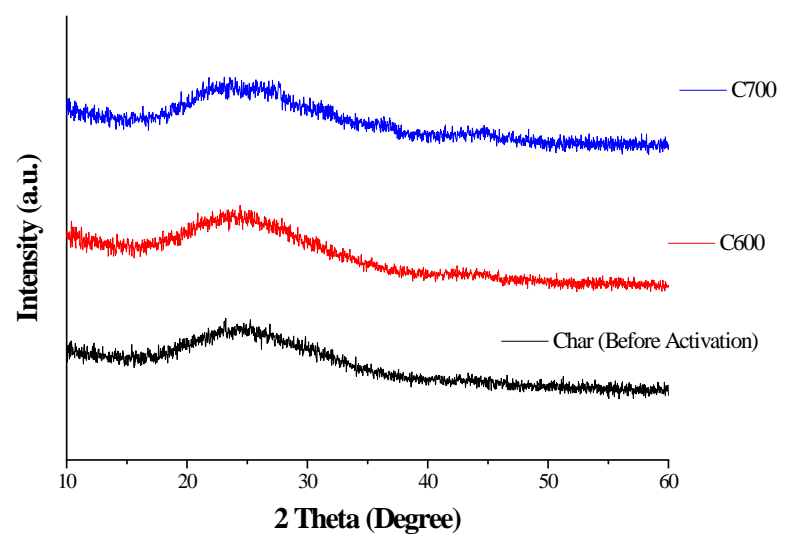

Fig. 2: XRD spectra of char, C600, and C700.

FTIR analysis showed some functional groups within the activated carbon that determine the surface properties of the activated carbon ${ }^{19,37,38)}$. The spectra are depicted in Fig. 2. and the observed-peaks are listed in Table 2.

The broad peak at $3422-3445 \mathrm{~cm}^{-1}$ is belonged to $\mathrm{O}-\mathrm{H}$ stretching vibration which is assigned to the hydroxyl group and phenol hydroxyl groups ${ }^{28,39)}$. A peak at 2883$2884 \mathrm{~cm}^{-1}$ represents the $\mathrm{C}-\mathrm{H}$ stretching ${ }^{40,41)}$. The $\mathrm{C}=\mathrm{O}$ stretching peak at $1712 \mathrm{~cm}^{-1}$ refers to the presence of aldehydes, carboxylic acids and ketone structure of cellulose and hemicellulose ${ }^{42,43)}$. Meanwhile, a peak at 1592-1570 $\mathrm{cm}^{-1}$ assigns to the $\mathrm{C}=\mathrm{C}$ bond stretching of aromatic ring ${ }^{28,41)}$, and a peak at $1092-1223 \mathrm{~cm}^{-1}$ refers to stretching of $\mathrm{C}-\mathrm{O}$ bond $^{28,29,42)}$. Fig. 3 shows that the activation process removes the $\mathrm{C}=\mathrm{O}$ peak, indicating thermal decomposition of aldehyde and ketone group in bagasse $^{43)}$. The intensity of C-O vibration peak increases in C700 (Fig. 3) that also increases its performance to adsorb water vapor ${ }^{28)}$.

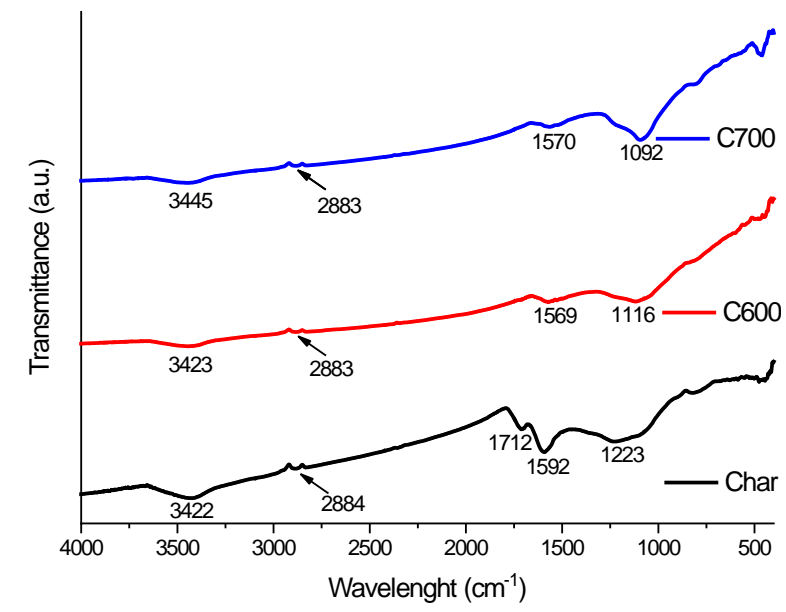

Fig. 3: FTIR spectra of Char, C600 and C700.

Table 2. The functional groups identified by FT-IR analysis to char, C600, and C700, and their literature.

\begin{tabular}{|c|c|c|c|c|}
\hline \multirow{2}{*}{$\begin{array}{l}\text { Functional } \\
\text { Group }\end{array}$} & \multicolumn{3}{|c|}{ Wavenumber $\left(\mathrm{cm}^{-1}\right)$} & \multirow{2}{*}{ References } \\
\hline & Char & $\mathrm{C600}$ & C700 & \\
\hline $\mathrm{C}-\mathrm{O}_{\text {stretching }}$ & 1223 & 1116 & 1092 & $28,29,42)$ \\
\hline $\mathrm{C}=\mathrm{C}_{\text {aromatic }}$ & 1592 & 1569 & 1570 & $28,41)$ \\
\hline $\begin{array}{l}\mathrm{C}=\mathrm{O}_{\text {stretching }} \\
\text { from cellulose, } \\
\text { hemicellulose } \\
\text { and lignin } \\
\text { vibration }\end{array}$ & 1712 & - & - & $42,43)$ \\
\hline $\mathrm{C}-\mathrm{H}_{\text {stretching }}$ & 2884 & 2883 & 2883 & $40,41)$ \\
\hline O-H $\mathrm{H}_{\text {stretching }}$ & 3422 & 3423 & 3445 & 28,39) \\
\hline
\end{tabular}

Elemental analysis of the prepared samples shows composition as listed in Table 3. with Carbon dominates the composition besides hydrogen, and nitrogen. The elemental composition is similar to the activated carbon prepared from coffee-shell ${ }^{28)}$.

Table 3. Elemental composition of char, C600, and C700.

\begin{tabular}{|l|l|l|l|l|}
\hline \multirow{2}{*}{ Sample } & \multicolumn{4}{|c|}{ Elemental Composition (\%) } \\
\cline { 2 - 5 } & $\mathbf{C}$ & $\mathbf{H}$ & $\mathbf{N}$ & Others \\
\hline $\begin{array}{l}\text { Char (before } \\
\text { activation) }\end{array}$ & 68.37 & 1.30 & 0.62 & 29.71 \\
\hline C600 & 66.30 & 0.58 & 0.28 & 32.84 \\
\hline C700 & 58.65 & 0.45 & 0.20 & 40.70 \\
\hline
\end{tabular}


The adsorption isotherm (Fig. 4) shows that the $\mathrm{N}_{2}$ adsorption-desorption isotherm in C600 follows type $\mathrm{V}$, meanwhile C700 follows type $\mathrm{IV}^{44-46)}$. Type $\mathrm{V}$ isotherm is belonged to microporous $(<2 \mathrm{~nm})-$ mesoporous ( $2 \mathrm{~nm}$ $50 \mathrm{~nm}$ ) materials. It indicates that $\mathrm{C} 600$ has microporous and also mesoporous pores, in which interaction between adsorbent-adsorbate is relatively weak ${ }^{41,45)}$. Meanwhile, C700 has type IV isotherm indicating C700 as a mesoporous material. Hysteresis loops of C600 and C700 are $\mathrm{H} 4$ and $\mathrm{H} 3$, respectively. $\mathrm{H} 4$ hysteresis loop is usually provided by porous material that consist of narrow pore channels from micro-mesoporous carbon. Meanwhile, H3 hysteresis loops indicates a slit-like pores ${ }^{44,45)}$.

The specific surface area of C600 and C700 are shown in Table 4. The BET specific surface area of C600 and C700 are $584.940 \mathrm{~m}^{2} / \mathrm{g}$ and $533.301 \mathrm{~m}^{2} / \mathrm{g}$, respectively. These results are higher than the other results produced by a different activation method, such as by $\mathrm{CO}_{2}$ activation which has BET surface area, $\mathrm{S}_{\mathrm{BET}}$, less than $370 \mathrm{~m}^{2} / \mathrm{g}^{47)}$, by chemical activation through microwave ultrasonic system using $\mathrm{KOH}$ and $\mathrm{H}_{2} \mathrm{SO}_{4}$ which produced activated carbon with $\mathrm{S}_{\mathrm{BET}}$ of $24.606 \mathrm{~m}^{2} / \mathrm{g}$ and $478.14 \mathrm{~m}^{2} / \mathrm{g}^{48)}$, respectively. The micropore structure of C600 mainly contributes to the large specific surface area of $\mathrm{C} 600^{46}$. Activation temperature seems to determines the surface area, and pore volume. Activation at $700{ }^{\circ} \mathrm{C}$ shows lower surface area and pore volume (see Table 4). It is caused by the lower carbon content, as it also found by other researches on preparing activated carbon by chemical and physical activation ${ }^{19,25}$.

Surface Area Analysis produces an isotherm curve as described in Fig. 4.

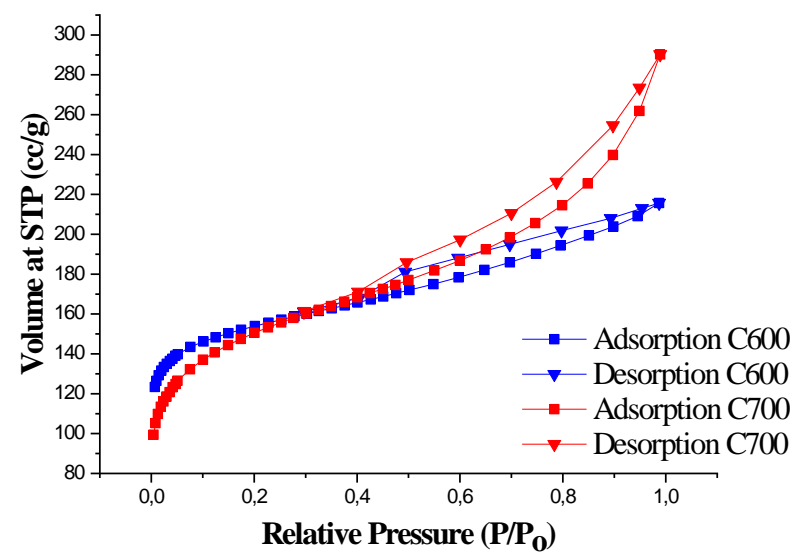

Fig. 4: Nitrogen adsorption - desorption isoterm of C600 and C700.

The micropore surface area of C600 is $77.30 \%$, which is higher than C700, i.e. $62.02 \%$. It indicates that C600 shows higher micropores activity than C700, in which the micropores fit with small molecules like water vapor ${ }^{41)}$.

The water vapor adsorption isotherm of C600 and C700 are shown in Fig. 5. Both are S-shaped indicates the microporous activated carbon. The isotherm is classified as type $\mathrm{V}$, as type for water adsorption on hydrophobic microporous - mesoporous adsorbents ${ }^{30,46,49,50)}$. As shown in Fig. 5, a small amount of water vapor adsorption at low relative pressure $\left(\mathrm{P} / \mathrm{P}_{0}<0.4\right)$, indicates that the activated carbon has hydrophobic surface characteristic ${ }^{30,50)}$.

Table 4. Spesific surface area and pore volume of activated

\begin{tabular}{|c|c|c|c|}
\hline Materials & $\mathrm{S}_{\text {BET }}$ & $S_{\text {micro }}$ & $V_{\text {micro }}$ \\
\hline C600 & $584.94 \mathrm{~m}^{2} / \mathrm{g}$ & $452.16 \mathrm{~m}^{2} / \mathrm{g}$ & $0.18 \mathrm{~cm}^{3} / \mathrm{g}$ \\
\hline C700 & $533.30 \mathrm{~m}^{2} / \mathrm{g}$ & $330.78 \mathrm{~m}^{2} / \mathrm{g}$ & $0.14 \mathrm{~cm}^{3} / \mathrm{g}$ \\
\hline
\end{tabular}

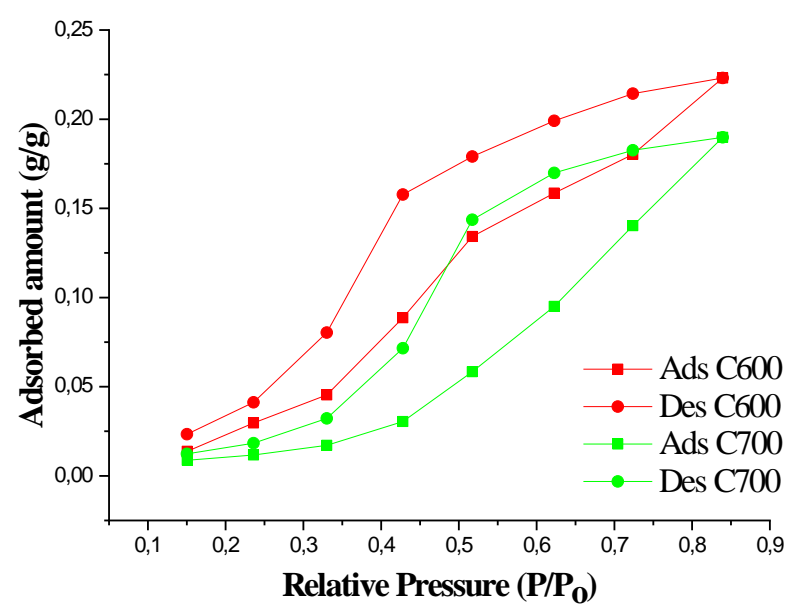

Fig. 5: Water Vapor Isotherm of C600 (red) and C700 (green) at $20^{\circ} \mathrm{C}$.

Adsorption of water vapor in a microporous material is generally follows "pore filling" mechanism ${ }^{51-53)}$. At first, adsorption occurs on the surface of activated carbon by interaction with oxygen atoms in a functional group with $\mathrm{O}$ atoms within. As the water vapor pressure increases, water molecules start to form clusters by forming hydrogen bonds with functional groups like hydroxyl groups and hydroxyl phenols. The hydroxyl functional groups are a strong hydrophilic group and tend to form hydrogen bonds with water molecules. When the pressure continues to increase, water molecules begin to fill the micropores on the activated carbon until saturated pressure. Pore filling in activated carbon starts from the smaller pores to the larger pores ${ }^{28,50,53)}$. The water vapor adsorption capacity of C600 and C700 are 0.22 g/g m 0.20 $\mathrm{g} / \mathrm{g}$, respectively. The higher microporosity and surface area of C600 produce higher water adsorption capacity than C700, indicating that the water vapor adsorption capacity of activated carbon increases as the specific surface area and microporosity increases. The study of water vapor adsorption of activated carbon by Sun et al. (2019) and Wang et al. (2013) showed a similar result, the water vapor capacity decreased as the activation temperature increased which was proportional to the surface area and total pore volume of activated carbon ${ }^{25,28)}$ This result revealed that the C600 has better adsorption performance than C700. 

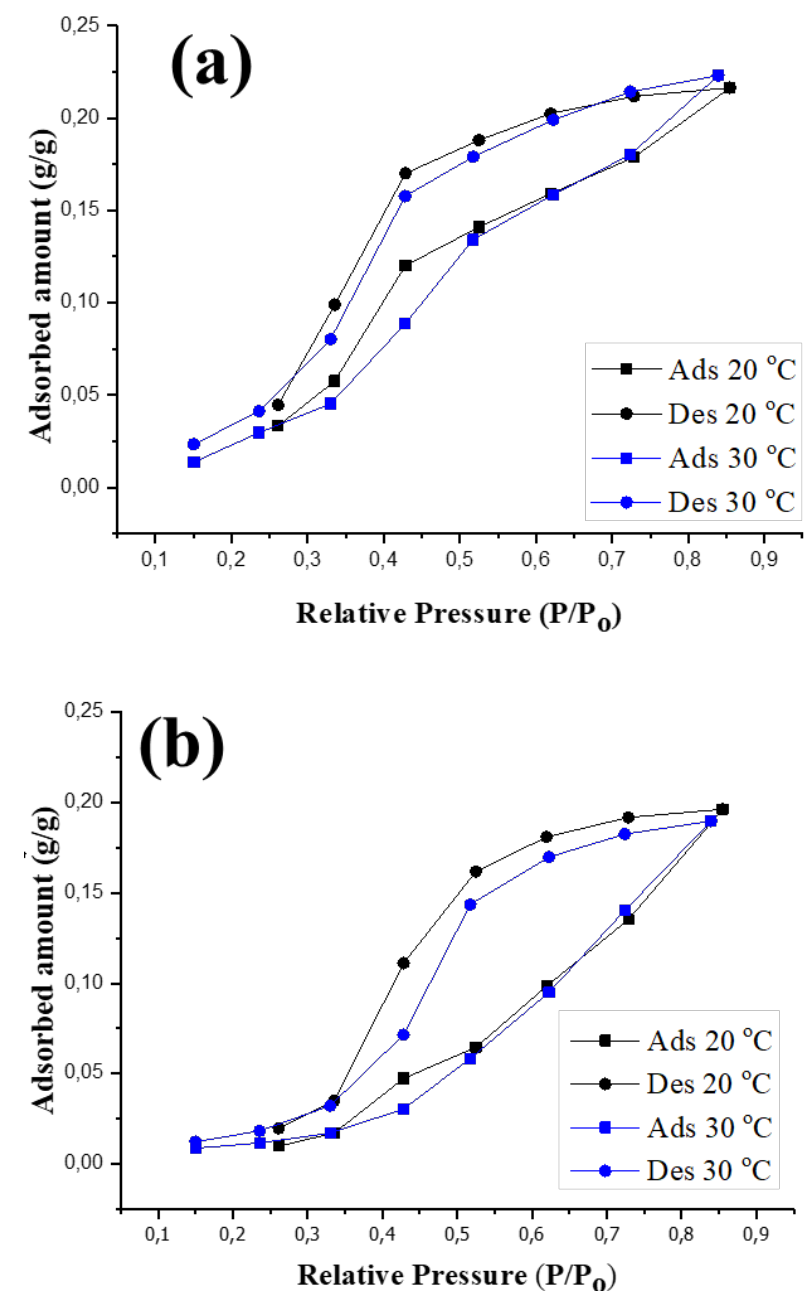

Fig. 6: Water isotherm for (a) $\mathrm{C} 600$ and (b) $\mathrm{C} 700$ at $20^{\circ} \mathrm{C}$ (black) and $30{ }^{\circ} \mathrm{C}$ (blue).

The study of temperature's effect on the water vapor adsorption isotherms are measured at $20^{\circ} \mathrm{C}$ and $30{ }^{\circ} \mathrm{C}$ up to the corresponding saturation pressure. The results in Fig. 6 show that the width of the hysteresis loop decreases as increasing temperature. The adsorption capacity of C600 at $20{ }^{\circ} \mathrm{C}$ and $30{ }^{\circ} \mathrm{C}$ are $0.217 \mathrm{~g} / \mathrm{g}$ and $0.223 \mathrm{~g} / \mathrm{g}$ respectively, while for $\mathrm{C} 700$ are $0.196 \mathrm{~g} / \mathrm{g}$ and 0.190 at $20{ }^{\circ} \mathrm{C}$ and $30{ }^{\circ} \mathrm{C}$, respectively. Fig. 6 shows an almost similar pattern between adsorption at 20 and $30{ }^{\circ} \mathrm{C}$. The amount of adsorbed water for C600 increased as a result of increasing temperature, while gives different results for C700. In the previous research by Horikawa et al. (2013), the adsorption capacity is higher with increasing temperature $^{54)}$. Meanwhile, another result on water vapor shows that the amounts of adsorbed water vapor decrease as the increase in temperature due to the poor thermal stability of water vapor within $0.193 \mathrm{~g} / \mathrm{g}$ of water vapor is absorbed at $30^{\circ} \mathrm{C}^{55}$ ). The higher result obtained by C600 shows the potency of C600 as adsorbent powder for water adsorption. Heating treatment during adsorption can promote swelling of clusters producing an undulating interface and the coalescence of clusters which facilitates the filling of the pore space ${ }^{50}$.

\section{Conclusion}

A high surface area of activated carbon was successfully prepared from bagasse, a solid waste of sugar cane factory, by conducting steam activation. The prepared activatedcarbon is dominated by micro pores structure. Activation at $600{ }^{\circ} \mathrm{C}$ produced higher BET surface are as well as higher water adsorption capacity than activation at $700{ }^{\circ} \mathrm{C}$ The maximum water adsorption is $0.22 \mathrm{~g} / \mathrm{g}$ obtained with C600 adsorbent at $30^{\circ} \mathrm{C}$. It shows that the Bagasse waste has a potency as raw material for adsorbent powder.

\section{Acknowledgements}

This research was funded by the Ministry of Research and Technology/National Agency for Research and Innovation, Indonesia and the Bilateral Exchanged Program JSPS/DG-RSTHE Joint Research Project 2019/2020 from Japan Society for the Promotion of Science.

\section{Nomenclature}

$Y_{1}$
$Y_{2}$
$Y_{3}$
$m_{1}$
$m_{2}$
$m_{3}$ The carbonization yield (\%) The activation yield (\%) The total yield (\%) The mass of the dried bagasse to be carbonized (g)

$m_{2} \quad$ The mass of resulting powder (char) after carbonization process (g)

$m_{3}$

$m_{4}$ The amount of the powder (char) used in the activation process (g) The amount of activated carbon (g)

\section{References}

1) S. Silveira, and D. Khatiwada, "Sugarcane Biofuel Production in Indonesia,” 2017. doi:10.1007/978-3030-18597-8.

2) Subdirectorate of Estate Crops Statistics, "Indonesian Sugar Cane Statistics 2017,” Jakarta, 2017.

3) Ministry of Agriculture, "Tree Crop Estate Statistic of Indonesia," Secretariate of Directorate General of Estate Crops, Jakarta, 2017.

4) H. Hajiha, and M. Sain, "The use of sugarcane bagasse fibres as reinforcements in composites," Biofiber Reinf. Compos. Mater., 525-549 (2014). doi:10.1533/9781782421276.4.525.

5) R. Wirawan, S.M. Sapuan, R. Yunus, and K. Abdan, "Properties of sugarcane bagasse / poly ( vinyl chloride ) composites after various treatments," (2010). doi:10.1177/0021998310385030.

6) Z. Huang, N. Wang, Y. Zhang, H. Hu, and Y. Luo, "Composites : part a effect of mechanical activation pretreatment on the properties of sugarcane bagasse / poly ( vinyl chloride ) composites," Compos. Part A, $43 \quad$ (1) 114-120 (2012). doi:10.1016/j.compositesa.2011.09.025. 
7) Y. Xu, Q. Wu, Y. Lei, and F. Yao, "Bioresource technology creep behavior of bagasse fiber reinforced polymer composites,” Bioresour. Technol., 101 (9) 3280-3286

(2010). doi:10.1016/j.biortech.2009.12.072.

8) C.S. Ajinomoh, "Production of activated carbon from sugar cane bagasse,” 16-22 (2008).

9) E.F. Mohamed, M.A. El-Hashemy, N.M. Abdel-Latif, and W.H. Shetaya, "Production of sugarcane bagassebased activated carbon for formaldehyde gas removal from potted plants exposure chamber," J. Air Waste Manag. Assoc., 65 (12) 1413-1420 (2015). doi:10.1080/10962247.2015.1100141.

10) R. Wirawan, and S.M. Sapuan, "Sugarcane BagasseFilled Poly (Vinyl Chloride) Composites,” Elsevier Ltd, 2018. doi:10.1016/b978-0-08-102160-6.00007$\mathrm{X}$.

11) S.Y. Sawant, K. Munusamy, R.S. Somani, M. John, B.L. Newalkar, and H.C. Bajaj, "Precursor suitability and pilot scale production of super activated carbon for greenhouse gas adsorption and fuel gas storage,” Chem. Eng. J., 315 415-425 (2017). doi:10.1016/j.cej.2017.01.037.

12) A.S. González, M.G. Plaza, F. Rubiera, and C. Pevida, "Sustainable biomass-based carbon adsorbents for post-combustion co 2 capture,” Chem. Eng. J., 230 456-465 (2013). doi:10.1016/j.cej.2013.06.118.

13) F. Rahmawati, V. Natalia, A.T. Wijayanta, K. Nakabayashi, J. Miyawaki, and S. Rondiyah, "Carbon waste powder prepared from carbon rod waste of zinc-carbon batteries for methyl orange adsorption,” Bull. Chem. React. Eng. Catal., 15 (1) 66-73 (2020). doi:10.9767/bcrec.15.1.5148.66-73.

14) J. Hou, C. Cao, F. Idrees, and X. Ma, "Hierarchical porous nitrogen-doped carbon nanosheets derived from silk for ultrahigh-capacity battery anodes and supercapacitors,” ACS Nano, 9 (3) 2556-2564 (2015). doi:10.1021/nn506394r.

15) Q. Wei, Z. Chen, Y. Cheng, X. Wang, X. Yang, and Z. Wang, "Preparation and electrochemical performance of orange peel based-activated carbons activated by different activators," Colloids Surfaces A Physicochem. Eng. Asp., 574 221-227 (2019). doi:10.1016/j.colsurfa.2019.04.065.

16) A.S. Brady-Estévez, S. Kang, and M. Elimelech, “A single-walled-carbon-nanotube filter for removal of viral and bacterial pathogens,” Small, 4 (4) 481-484 (2008). doi:10.1002/smll.200700863.

17) W. Zhao, L. Luo, H. Wang, and M. Fan, "Synthesis of bamboo-based activated carbons with super-high specific surface area for hydrogen storage," BioResources, $12 \quad$ (1) 1246-1262 (2017). doi:10.15376/biores.12.1.1246-1262.

18) F. Rahmawati, S. Wahyuningsih, and D. Irianti, "The photocatalytic activity of sio2-tio2/graphite and its composite with silver and silver oxide,” Bull. Chem. React. Eng. Catal., 9 (1) 45-52 (2014). doi:10.9767/bcrec.9.1.5374.45-52.

19) S. Yorgun, and D. Yildiz, "Preparation and characterization of activated carbons from paulownia wood by chemical activation with h3po4,” J. Taiwan Inst. Chem. Eng., 53 122-131 (2015). doi:10.1016/j.jtice.2015.02.032.

20) J. Miyawaki, J. Yeh, H. Kil, and J. Lee, “Influence of pore size and surface functionality of activated carbons on adsorption behaviors of indole and amylase influence of pore size and surface functionality of activated carbons on adsorption behaviors of indole and amylase," Evergr. Jt. J. Nov. Carbon Resour. Sci. Green Asia Strateg., 3 (2) 17-24 (2016). doi:10.5109/1800868.

21) I.S. Banuwa, K.F. Hidayat, I. Zulkarnain, P. Sanjaya, Afandi, and A. Rahmat, "Soil loss and cassava yield under ridge tillage in humid tropical climate of sumatera, indonesia,” Int. J. GEOMATE, 18 (67) 1-7 (2020). doi:10.21660/2020.67.78211.

22) F. Ohashi, M. Maeda, K. Inukai, M. Suzuki, and S. Tomura, "Study on intelligent humidity control materials: water vapor adsorption properties of mesostructured silica derived from amorphous fumed silica,” J. Mater. Sci., 34 (6) 1341-1346 (1999). doi:10.1023/A:1004510417593.

23) Y. Liu, H. Jia, G. Zhang, Z. Sun, Y. Pan, and S. Zheng, "Synthesis and humidity control performances of natural opoka based porous calcium silicate hydrate," Adv. Powder Technol., 30 (11) 2733-2741 (2019). doi:10.1016/j.apt.2019.08.020.

24) I. Durán, F. Rubiera, and C. Pevida, "Biogas puri fi cation by means of adsorption on pine sawdust-based activated carbon : impact of water vapor," Chem. Eng. J., $353 \quad$ (July) 197-207 (2018). doi:10.1016/j.cej.2018.07.100.

25) R. Wang, Y. Amano, and M. Machida, "Surface properties and water vapor adsorption-desorption characteristics of bamboo-based activated carbon,” $J$. Anal. Appl. Pyrolysis, 104 667-674 (2013). doi:10.1016/j.jaap.2013.04.013.

26) M.H. Mahmood, M. Sultan, and T. Miyazaki, "Study on water-vapor adsorption onto polymer and carbon based adsorbents for air-conditioning applications," Evergr. Jt. J. Nov. Carbon Resour. Sci. Green Asia Strateg., 06 (03) 215-224 (2019).

27) D. Bergna, T. Varila, H. Romar, and U. Lassi, "Comparison of the properties of activated carbons produced in one-stage and two-stage processes," C, 4 (3) 41 (2018). doi:10.3390/c4030041.

28) S. Sun, Q. Yu, M. Li, H. Zhao, and C. Wu, "Preparation of coffee-shell activated carbon and its application for water vapor adsorption,” Renew. Energy, $142 \quad 11-19$ (2019). doi:10.1016/j.renene.2019.04.097.

29) J. Wu, H. Xia, L. Zhang, Y. Xia, J. Peng, S. Wang, Z. Zheng, and S. Zhang, "Effect of microwave heating conditions on the preparation of high surface area 
activated carbon from waste bamboo," High Temp. Mater. Process., $34 \quad$ (7) 667-674 (2015). doi:10.1515/htmp-2014-0096.

30) Q. Yu, H. Zhao, H. Zhao, S. Sun, X. Ji, M. Li, and Y. Wang, "Preparation of tobacco-stem activated carbon from using response surface methodology and its application for water vapor adsorption in solar drying system,” 177 (October 2018) 324-336 (2019). doi:10.1016/j.solener.2018.11.029.

31) B. Wang, B. Gao, and J. Fang, "Recent advances in engineered biochar productions and applications," Crit. Rev. Environ. Sci. Technol., 47 (22) 2158-2207 (2017). doi:10.1080/10643389.2017.1418580.

32) G. Selvaraju, N. Kartini, and A. Bakar, "Journal of the taiwan institute of chemical engineers process conditions for the manufacture of highly micromesoporous eco-friendly activated carbon from artocarpus integer bio-waste by steam activation,” 93 414-426 (2018). doi:10.1016/j.jtice.2018.08.011.

33) P. Nai, Y. Yek, R. Keey, M. Shahril, C. Leing, J. Huang, Y. Park, and S. Shiung, "Microwave steam activation, an innovative pyrolysis approach to convert waste palm shell into highly microporous activated carbon,” J. Environ. Manage., 236 (January) 245-253 (2019). doi:10.1016/j.jenvman.2019.01.010.

34) J. Pallarés, A. González-cencerrado, and I. Arauzo, "Biomass and bioenergy production and characterization of activated carbon from barley straw by physical activation with carbon dioxide and steam,” Biomass and Bioenergy, 115 (January) 6473 (2018). doi:10.1016/j.biombioe.2018.04.015.

35) A. Li, H. Wang, J. Han, and L. Liu, "Preparation of a pb loaded gas diffusion electrode and its application to co2 electroreduction,” Front. Chem. Sci. Eng., 6 (4) 381-388 (2012). doi:10.1007/s11705-012-1216-2.

36) H. Peng, G. Hao, Z. Chu, Y. Lin, X. Lin, and Y. Cai, "RSC advances a metal - organic framework as a lithium-ion battery," RSC Adv., 7 34104-34109 (2017). doi:10.1039/C7RA05090A.

37) K.E. Brennan, J. K.; Bandosz, T. J.; Thomson, K. T.; Gubbins, "Water in porous carbons. colloids and surfaces,” Physico- Chem. Eng. Asp., 187 187-188, 539-568 (2001). doi:10.1016/S09277757(01)00644-6.

38) A. Özhan, Ö. Şahin, M.M. Küçük, and C. Saka, "Preparation and characterization of activated carbon from pine cone by microwave-induced zncl2 activation and its effects on the adsorption of methylene blue,” Cellulose, 21 (4) 2457-2467 (2014). doi:10.1007/s10570-014-0299-y.

39) F. Guo, X. Jiang, X. Jia, S. Liang, L. Qian, and Z. Rao, "Synthesis of biomass carbon electrode materials by bimetallic activation for the application in supercapacitors,” J. Electroanal. Chem., 844 (January) 105-115 (2019). doi:10.1016/j.jelechem.2019.05.004.
40) A.M. Puziy, O.I. Poddubnaya, A. Martínez-Alonso, F. Suárez-García, and J.M.D. Tascón, "Synthetic carbons activated with phosphoric - acid i. surface chemistry and ion binding properties," Carbon N. Y., 40 (9) 1493-1505 (2002). doi:10.1016/S00086223(01)00317-7.

41) L. Zhang, L.Y. Tu, Y. Liang, Q. Chen, Z.S. Li, C.H. Li, Z.H. Wang, and W. Li, "Coconut-based activated carbon fibers for efficient adsorption of various organic dyes," RSC Adv., 8 (74) 42280-42291 (2018). doi:10.1039/c8ra08990f.

42) H. Ahmed Baloch, S. Nizamuddin, M.T.H. Siddiqui, N.M. Mubarak, D.K. Dumbre, M.P. Srinivasan, and G.J. Griffin, "Sub-supercritical liquefaction of sugarcane bagasse for production of bio-oil and char: effect of two solvents,” J. Environ. Chem. Eng., 6 (5) 6589-6601 (2018). doi:10.1016/j.jece.2018.10.017.

43) M.S. Shamsuddin, N.R.N. Yusoff, and M.A. Sulaiman, "Synthesis and characterization of activated carbon produced from kenaf core fiber using h 3 po 4 activation,” Procedia Chem., 19 558565 (2016). doi:10.1016/j.proche.2016.03.053.

44) Z.A. Alothman, “A review: fundamental aspects of silicate mesoporous materials,” 5 2874-2902 (2012). doi:10.3390/ma5122874.

45) M. Thommes, K. Kaneko, A. V. Neimark, J.P. Olivier, F. Rodriguez-Reinoso, J. Rouquerol, and K.S.W. Sing, "Physisorption of gases, with special reference to the evaluation of surface area and pore size distribution (iupac technical report),” Pure Appl. Chem., 87 (910) 1051-1069 (2015). doi:10.1515/pac-2014-1117.

46) K.S.W. Sing, "REPORTING physisorption data for gas / solid systems with special reference to the determination of surface area and porosity,” 57 (4) 603-619 (1985). doi:10.5109/2349297.

47) A. Singh, and D. Lal, "Influence of heating rate and temperature on carbon structure and porosity of activated carbon spheres from resole-type phenolic beads," Carbon Lett., 10 (3) 181-189 (2009). doi:10.5714/cl.2009.10.3.181.

48) N.M. Zawawi, F. Hamzah, M. Sarif, S. Fairuz, A. Manaf, and A. Idris, "MALAYSIAN journal of analytical sciences characterization of activated carbon using chemical activation via microwave ultrasonic system (pencirian karbon teraktif menggunakan sistem pengaktifan kimia melalui ketuhar gelombang ultrasonik)," Malaysian J. Anal. Sci., 21 (1) 159-165 (2017). doi:10.17576/mjas2017-2101-18.

49) H. Abiko, "Water vapor adsorption and desorption isotherms of activated carbon products used in japanese gas respirators,” Tanso, 248 127-132 (2011). doi:10.7209/tanso.2011.127.

50) L. Liu, S. (Johnathan) Tan, T. Horikawa, D.D. Do, D. Nicholson, and J. Liu, "Water adsorption on carbon a review,” Adv. Colloid Interface Sci., 250 64-78 (2017). doi:10.1016/j.cis.2017.10.002. 
51) M.M. Dubinin, "Generalization of the theory of volume filling of micropores to nonhomogeneous microporous structures,” Carbon N. Y., 23 (4) 373380 (1985). doi:10.1016/0008-6223(85)90029-6.

52) X.J. Liu, Y.F. Shi, M.A. Kalbassi, R. Underwood, and Y.S. Liu, "Water vapor adsorption isotherm expressions based on capillary condensation," Sep. Purif. Technol., $116 \quad 95-100 \quad$ (2013). doi:10.1016/j.seppur.2013.05.020.

53) M.M. Dubinin, "Water vapor adsorption and the microporous structures of carbonaceous adsorbents," Carbon N. Y., $18 \quad$ (5) 355-364 (1980). doi:10.1016/0008-6223(80)90007-X.

54) T. Horikawa, N. Sakao, and D.D. Do, "Effects of temperature on water adsorption on controlled microporous and mesoporous carbonaceous solids," Carbon N. $\quad$ Y., $\quad 56 \quad 183-192 \quad$ (2013). doi:10.1016/j.carbon.2013.01.003.

55) X.L. Yao, L.Q. Li, H.L. Li, and W.W. Ma, “A simplified adsorption model for water vapor adsorption on activated carbon,” J. Cent. South Univ., 21 (4) 1434-1440 (2014). doi:10.1007/s11771-0142082-5. 